\title{
PD-L1 testing, fit for routine evaluation? From a pathologist's point of view
}

\author{
Georg Hutarew (D)
}

Received: 11 August 2016 / Accepted: 4 October 2016 / Published online: 28 October 2016 (C) The Author(s) 2016. This article is available at SpringerLink with Open Access.

\begin{abstract}
Summary Tumours with high somatic mutation rates escape immune surveillance by upregulating receptors and ligands such as programmed death receptor1 and its ligand (PD-1/PD-L1). Checkpoint inhibitors (ICI) provide encouraging therapeutic results in nonsmall cell lung cancers (NSCLC) and may soon be used in 2nd or 1st line therapy. Currently PD-L1 immunohistochemistry (IHC) expression assessed on tumour cells is used as a predictive biomarker, since better patient outcomes are often, but not always associated with increased tumour cell PD-L1 IHC expression. However pre-analytical variables, different antiPD-L1 clones used on different staining platforms, different specimens types, as well as intra- and interobserver variability influence the results. We will only understand PD-L1 expression on tumour cells if we accept that PD-L1 is an inducible pathophysiological factor with variable levels of PD-L1 expression depending on the immunological status. Should we test PD-Ll during initial diagnostic work up before, or at the point when immune checkpoint therapy is considered? Taking all arguments into account the value of PD-L1 as a predictive biomarker is questionable. Other predictive biomarkers such as high mutation burden, mRNA expression, neo-antigens and the diversity of tumour antigen-specific $\mathrm{T}$ cells should be evaluated in the future. Here we review results presented in 30 journal articles and three reviews covering this topic in the last 3 years.
\end{abstract}

Keywords Immune checkpoint inhibitors · PD-1 · PDL1 $\cdot$ Immunohistochemistry $\cdot$ Biomarker assay

\section{G. Hutarew, MD ( $\bowtie)$}

Department of Pathology, University Hospital and

Paracelsus Medical University Salzburg, Müllner

Hauptstraße 48, 5020 Salzburg, Austria

hutarew@elsnet.at

\section{Immune receptors and ligands}

Within their microenvironment tumour cells can modify the immune response, which comprises a dynamic balance of multifactorial interactions with stimulating and inhibitory receptors and ligands of immune cells. The same mechanisms help create immune tolerance and prevent autoimmune diseases [1]. Particularly tumours with a high rate of somatic mutations such as lung cancers or melanomas are immunogenic [2-5]. They induce upregulation of receptors and ligands such as the programmed death receptor-1 and its ligand (PD-1/PD-L1) and B7/CTLA4 , and consequently they escape immune surveillance. Checkpoint inhibitors, especially monoclonal antibodies against PD-1 and its ligand PD-L1 have proven to provide a promising therapeutic approach in non-small cell lung cancer (NSCLC) [1, 6-10].

\section{PD-L1 IHC expression as a predictive biomarker}

Today numerous PD-1 inhibitors are available such as nivolumab (Opdivo, Bristol Myers Squibb, NY, USA) and pembrolizumab (Keytruda, MSD, Kenilworth, NJ, USA) or PD-L1 inhibitors such as durvalumab (AstaZeneca, London, UK), atezolizumab (Roche, Basel, Switzerland) and avelumab (Pfizer/Merck Serono, Berlin/Darmstadt, Germany). Since checkpoint inhibitors may be used in 2nd or 1st line therapy in the near future, it is important to define a reliable predictive biomarker. One candidate is the expression of PD-L1 assessed by immunohistochemistry (IHC) especially on tumour cells [5, 7]. A number of PD-L1 antibody clones are available as prepackaged kits or as free antibodies, using different staining platforms and different staining protocols as well as different scoring systems and different cut offs for predictive evaluation (Table 1; [7]). They can be used on Ventana 
Table 1 Specifications of PD-L1 Antibody Clones

\begin{tabular}{|c|c|c|c|c|c|c|}
\hline $\begin{array}{l}\text { Antibody clone/ } \\
\text { test }\end{array}$ & $\begin{array}{l}\text { Source and } \\
\text { clonality }\end{array}$ & Cdx for drug & Mechanism & Cutpoint & Staining system & Compartment \\
\hline $\begin{array}{l}\text { VENTANA PD-L1 } \\
(\mathrm{SP} 263)^{b}\end{array}$ & $\begin{array}{l}\text { Rabbit mono- } \\
\text { clonal }\end{array}$ & $\begin{array}{l}\text { Durvalumab (As- } \\
\text { traZeneca) }\end{array}$ & Anti PD-L1 & $\mathrm{TC} \geq 25 \%$ & Ventana UItra & $\begin{array}{l}\text { Tumour cell mem- } \\
\text { brane }\end{array}$ \\
\hline $\begin{array}{l}\text { PD-L1 IHC 28-8 } \\
\text { pharmDx } \\
\text { Dakob }^{\text {b }}\end{array}$ & $\begin{array}{l}\text { Rabbit mono- } \\
\text { clonal }\end{array}$ & Nivolumab (BMS) & Anti PD-1 & $\mathrm{TC} \geq 1 \%$ & $\begin{array}{l}\text { Dako Au- } \\
\text { tolink } 48\end{array}$ & $\begin{array}{l}\text { Tumour cell mem- } \\
\text { brane }\end{array}$ \\
\hline 28-8 Abcam ${ }^{b}$ & $\begin{array}{l}\text { Rabbit mono- } \\
\text { clonal }\end{array}$ & - & - & $\mathrm{TC}^{\mathrm{C}}$ & $\begin{array}{l}\text { Multiple plat- } \\
\text { forms }\end{array}$ & $\begin{array}{l}\text { Tumour cell mem- } \\
\text { brane }\end{array}$ \\
\hline $\begin{array}{l}\text { PD-L1 IHC 22C3 } \\
\text { pharmDx } \\
\text { Dakob }^{b}\end{array}$ & $\begin{array}{l}\text { Mouse mono- } \\
\text { clonal }\end{array}$ & $\begin{array}{l}\text { Pembrolizumab } \\
\text { (Merck USA) }\end{array}$ & Anti PD-1 & $\mathrm{TC} \geq 1 \%$ & $\begin{array}{l}\text { Dako Au- } \\
\text { tolink } 48\end{array}$ & $\begin{array}{l}\text { Tumour cell mem- } \\
\text { brane }\end{array}$ \\
\hline 22C3 DAKO & $\begin{array}{l}\text { Mouse mono- } \\
\text { clonal }\end{array}$ & - & - & $\mathrm{TC}^{\mathrm{C}}$ & $\begin{array}{l}\text { Multiple plat- } \\
\text { forms }\end{array}$ & $\begin{array}{l}\text { Tumour cell mem- } \\
\text { brane }\end{array}$ \\
\hline $\begin{array}{l}\text { PD-L1/CD274 } \\
\text { (SP142) Spring }\end{array}$ & $\begin{array}{l}\text { Rabbit mono- } \\
\text { clonal }\end{array}$ & Atezolizumab (Roche) & Anti PD-L1 & TC and/or IC see Table 2 & Ventana UItra & $\begin{array}{l}\text { Tumour cell mem- } \\
\text { brane and Immune } \\
\text { cells }\end{array}$ \\
\hline $\begin{array}{l}\text { E1L3N Cell } \\
\text { signaling }^{\mathrm{a}}\end{array}$ & $\begin{array}{l}\text { Rabbit mono- } \\
\text { clonal }\end{array}$ & - & - & $\mathrm{TC}^{\mathrm{C}}$ & $\begin{array}{l}\text { Multiple plat- } \\
\text { forms }\end{array}$ & $\begin{array}{l}\text { Tumour cell mem- } \\
\text { brane }\end{array}$ \\
\hline $\begin{array}{l}\text { CAL10 Biocare } \\
\text { Medical }^{a}\end{array}$ & $\begin{array}{l}\text { Rabbit mono- } \\
\text { clonal }\end{array}$ & - & - & $\mathrm{TC}^{\mathrm{C}}$ & $\begin{array}{l}\text { Multiple plat- } \\
\text { forms }\end{array}$ & $\begin{array}{l}\text { Tumour cell mem- } \\
\text { brane }\end{array}$ \\
\hline
\end{tabular}

Ultra Systems, DAKO Autolink 48 stainers or others with or without enhancement systems (Figs. 1 and 2).

\section{Is there an optimal threshold?}

The results of "The Blueprint PD-L1 IHC Assay Comparison Project”, a phase I study, were presented by Dr. Hirsch et al. at the recent 2016 Annual Meeting of the AACR. In this study three of four assays were analytically similar for tumour cell staining, i. e. SP263, 28-8 and 22C3, but no clinical diagnostic cut-off was applied in the project. At the same AACR meeting, M. Ratcliffe presented "A Comparative Study of PDL1 Diagnostic Assays". Evaluating 500 biopsy samples including both squamous and non-squamous histology and showed that a $25 \%$ cut-off point using Ventana SP263 was similar to the results obtained from a DAKO $28-8$ test at $10 \%$ cut-off mark. The results from the SP263 and the Dako 22C3 tests were similar at a cut-off of $50 \%$. All three tests agreed overall in more than $90 \%$ of cases.

In a review by Kerr et al. [6], the calculated rate of positivity in 10 analysed studies for PD-L1 was between 13 and $70 \%[11-14]$ and the correlation between treatment and biomarker response rate was given as 13-83\% depending upon the cut-offs, the specific antibody clones as well as the therapeutic agent used $[7,15]$. Tumour proportion scores (TPS) were defined as the percentage of tumour cells with complete or partial membranous staining at any intensity. A wide range of cut-off points determined IHC positivity with values of $1,5,10,25$ and $50 \%$ [11, 16-18]. Commonly high expression of PD-L1 indicates a better therapy response [5, 7, 13, 16, 19-23] and showed improv- ing hazard ratios for overall survival (OS) and progression free survival (PFS) with increasing levels of PDL1 staining [24]. Nevertheless many studies also report significant response rates (3-20\%) in PD-L1 IHCnegative cases [6, 12, 15, 25].

Khunger et al. presented "Meta-analysis of tumour PD-L1 expression as a predictive biomarker of benefit from PD-1/PD-L1 axis inhibitors in solid tumours" at ASCO 2016. The analysis evaluated 18 studies with 2731 patients. Inclusion criteria were different tumours with high mutational burden, with 9 studies of NSCLC with known IHC PD-L1 status and PD1/PDL1 inhibitor treatment. A threshold of $5 \%$ PD-L1 IHC expression was highly predictive for different drugs as nivolumab, pembrolizumab, atezolimumab, durvalumab and avelumab. The largest therapeutic effect was seen in NSCLC $(\mathrm{OR}=3.33 ; 95 \%$ CI 2.52-4.40, $p<$ $0.001)$. The authors concluded that $5 \%$ tumour PDL1 expression as a threshold of PD-L1 expression may be optimal.

Results of the phase III CheckMate057 study [12] showed that PD-L1 IHC with a cut-off point of $1 \%$ correlated with ORR and PFS in pretreated NSCLC. Likewise Passiglia et al. [15] calculated a threshold of $1 \%$ for PD-L1 expression based on evaluating 7 studies with 914 patients with PD-L1 positive tumours. These patients had a significantly higher ORR, than patients with PD-L1 negative tumours (OR: 2.44; $95 \%$ CI 1.61-3.68) [15].

Kerr et al. reported the use of different thresholds in different biomarker studies using the example of nivolumab $[1,5]$. Trials of this agent used anti-PDL1 IHC antibody clone 28-8 (Dako, Glostrup, Denmark) with cut-off points of $\geq 1, \geq 5$ and $\geq 10 \%$ to define 

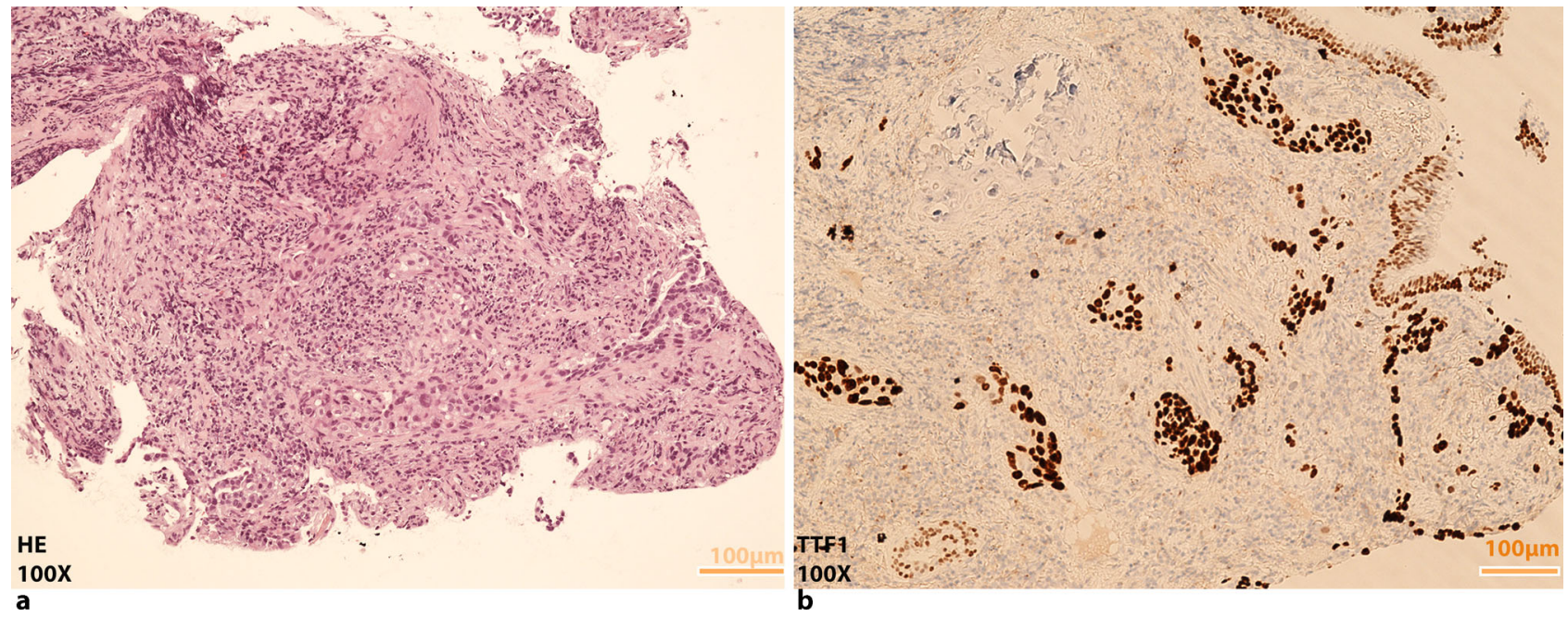

Fig. 1 Pulmonary adenocarcinoma. $\mathbf{a} \mathrm{HE}$ and $\mathbf{b}$ positive TTF1 staining, both images $\times 100$ magnification

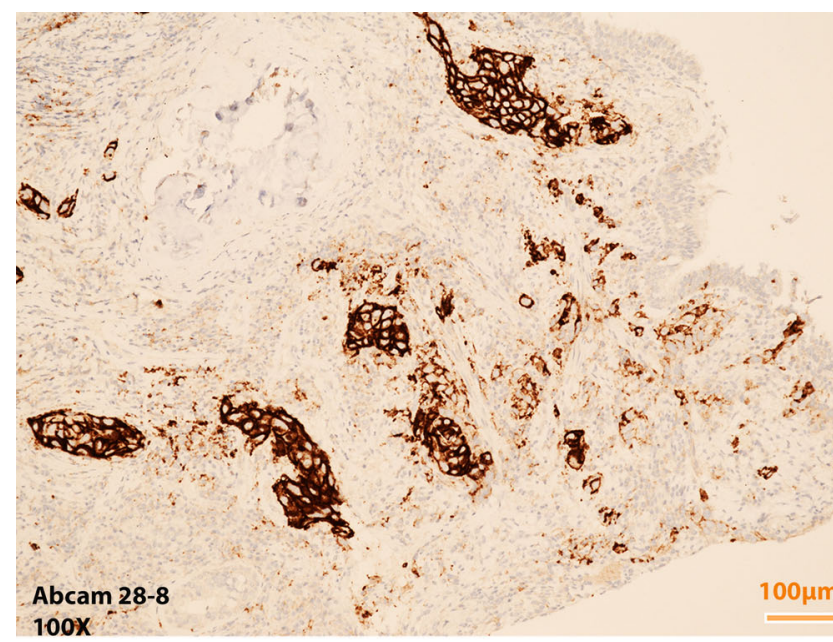

a
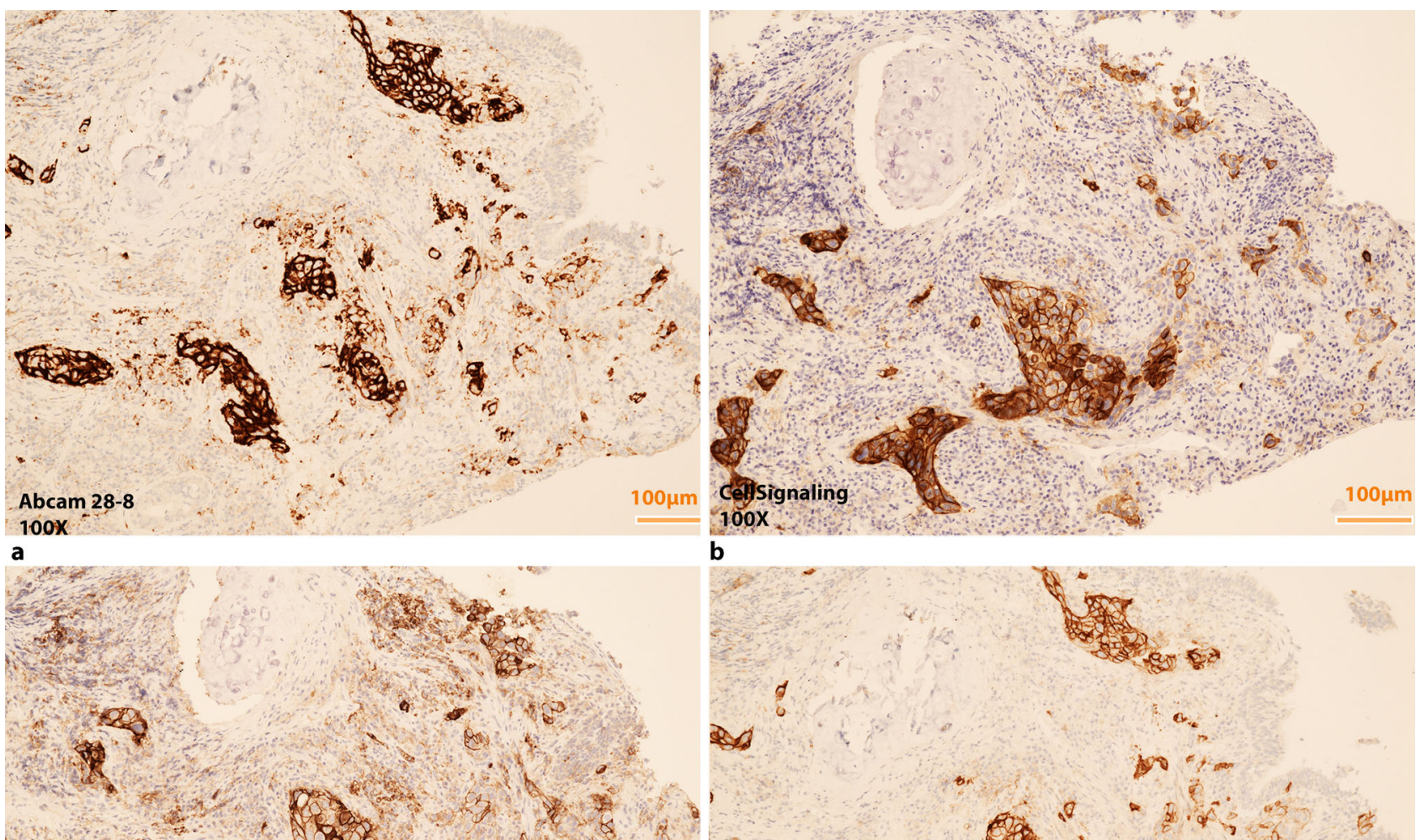

b
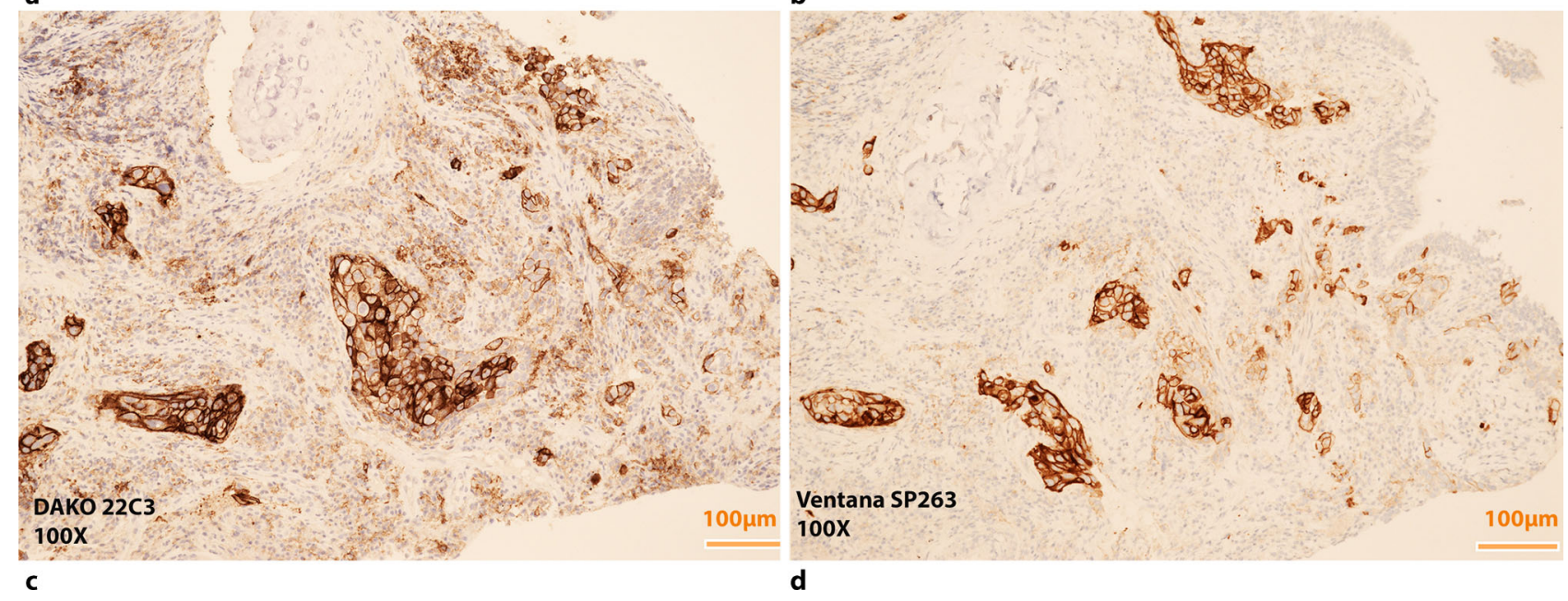

Fig. 2 Images of the TTF1 + pulmonary adenocarcinoma seen in Fig. 1 stained positive with different PD-L1 antibody clones, Crosstesting, (a,b)Abcam 28-8 and Cell Signaling E1 L3N and, both stained on VentanaUltra with OptiView, (c,d) DAKO Pharm DX22C3 and Ventana SP263, both prepackaged kits. Scoring does not evaluate intensity therefore enhancement systems such as OptiView can be used without altering the results. All images $\times 100$ magnification 
Table 2 PD-L1 scoring convention for TC and IC expression detected by Ventana SP 142

\begin{tabular}{|c|c|c|c|}
\hline $\begin{array}{l}\text { Description PD-L1 staining } \\
(\%)\end{array}$ & IC score & $\begin{array}{l}\text { Description PD-L1 TC } \\
\text { staining (\%) }\end{array}$ & TC score \\
\hline$I C \geq 10$ & IC3 & $\mathrm{TC} \geq 50$ & TC3 \\
\hline IC $\geq 5$ and $<10$ & IC2 & $\mathrm{TC} \geq 5$ and $<50$ & TC2 \\
\hline IC $\geq 1$ and $<5$ & IC1 & $\mathrm{TC} \geq 1$ and $<5$ & TC1 \\
\hline IC $<1$ & ICO & $\mathrm{TC}<1$ & TCO \\
\hline
\end{tabular}

positive staining [13]. Eventually, nivolumab was approved without the need for complementary diagnostic. Biomarker tests for pembrolizumab used anti-PDL1 Dako clone 22C3 with two different cut-offs of $\geq 1 \%$ and $\geq 50 \%$ in the conducted study to define positive staining and for clinical use, $\geq 50 \%$ TPS was considered positive [20, 26, 27]. Meanwhile pembrolizumab has been approved by the EMA with a cut-off point of $1 \%$ with any approved IHC test similar to 22C3. Durvalumab uses the anti-PD-L1 Ventana SP263 antibody clone with a cut off of $\geq 25 \%$ [25].

\section{PD-L1 testing on immune cells and/or tumour cells}

Azetolizumab with SP142 Ventana as a companion diagnostic requires assessment of TC and/or tumourassociated immune cells (ICs) (Table 2; [23]).

Herbst et al. [4] showed that PD-L1 expression on tumour infiltrating immune cells predicts responses to atezolizumab better than PD-L1 expression on tumour cells. Teng et al. reported that combining IHC PD-L1 expression status of tumour-infiltrating lymphocytes and tumour cells might help to select patients for combination therapies $[5,28]$.

Biomarker expression in lymphoid or other immune effector cells is a special challenge for pathologists. Inter- and intra-observer bias for TILs is lower than for tumour cells [28], the pathologist cannot always recognize whether the existing lymphocyte population is oncogene or inflammation driven [23, 28]. Scheel et al. showed that reproducible PD-L1 IHC scoring of tumour cells seems feasible whereas scoring of immune cells did not yield reproducible results [29].

The threshold that discriminates between therapy responders and nonresponders should be calculated from collected response data; however it is not clear whether benefit from immunotherapy might be better described by progression-free or overall survival data than by overall response rate $[3,10,16,20]$. Studies suggest that traditional response criteria may not be able to fully capture the immune-therapy activity [15].

\section{Does heterogeneity of lung cancer influence PD-L1 results?}

PD-L1 expression results might not represent the true PD-L1 status of a tumour due to the heterogeneity of PD-L1 expression in lung cancer, this is especially challenging if only biopsies are evaluated [1]. Kerr and other authors [1, 5, 16] stated that in a multifactorial dynamic system reacting sensitive to changes, any earlier form of chemotherapy or targeted therapy may induce PD-L1 expression. The opposite was reported by Herbst et al. in abstract 3030 ASCO 2016 "Archival vs new tumour samples for assessing PDL1 expression in the KEYNOTE-010 study". The distribution of PD-L1 (TPS $1-49 \%$ and $>50 \%$ ) was similar in archival and newly collected tumour samples of patients with previously treated NSCLC. These data suggest that a new tumour biopsy sample may not be required at the time when ICI therapy is considered, questioning the value of rebiopsy.

\section{Does histology affect PD-L1 testing?}

Patients with squamous cell carcinomas treated with nivolumab did not show improvements in PFS and OS dependent on the level of PD-L1 expression [3]. In patients with non-squamous cell carcinoma treated with nivolumab or docetaxel, the nivolumab treated group with positive PD-L1 IHC expression showed better PFS and OFS [12]. Hence mainly tumours with non-squamous histology should be tested for PD-L1 expression in lung cancer.

\section{Standardizing PD-L1 testing}

PD-L1 tests must be reproducible, both the technical procedure of staining and the interpretation of the test by pathologists. Pre-analytical issues such as tissue fixation and processing have a major impact on the outcomes of immunohistochemical reactions [14, 21] and might affect the results of different PD-L1 IHC tests.

Standardization of these biomarker tests can be reached by using exclusively prepackaged test kits of reagents running on company-specific staining platforms with an industry standard [24]. However free antibody clones such as Abcam 28-8, Cell signalling E1L3N and others are less expensive than their prepackaged counterparts and can be established on different staining platforms without quality impairment. The results obtained from cross testing PD-L1 IHC 28-8 pharmDx on Autostainer Link 48 versus Anti-PD-L1 antibody 28-8 (Abcam) on Ventana Ultra with OptiView in our department showed no sig- 
nificant differences in staining results (unpublished data). Worldwide numerous cross-assay validations and interlaboratory tests (round robin tests) are performed to determine the reproducibility of PDL1 immunohistochemistry yet without having found a gold standard.

\section{Other predictive biomarkers}

Upcoming biomarkers may include the high mutation burden within the PD-Ll positive tumour cell group, expression of neo antigens, the diversity of the $\mathrm{T}$ cell repertoire and PD-L1 mRNA expression [30].

\section{Conclusion}

PD1/PD-L1 biology is complex with conflicting results from different studies. Moreover PD-L1 IHC does not fulfil the strict criteria of a biomarker as anaplastic lymphoma kinase (ALK) translocation or epidermal growth factor receptor (EGFR) mutation does. Nevertheless PD-L1 IHC expression seems to be the best currently available biomarker and may be indicative of a dose-response relationship between PD-L1 expression and drug efficacy. A low threshold such as a PDL1 TPS of $1 \%$ allows us to include nearly all patients who may really benefit from these therapies. However, since it may be inappropriate to select patients for ICI therapy solely on the basis of PD-L1 expression other predictive biomarkers should be established. In advanced lung cancer plasma PD-L1 protein could provide a promising alternative for monitoring PDL1 levels. PDL1-enzyme linked immunosorbent assay (PDL1-ELISA) can analyse PDL1 quantitatively or qualitatively in plasma and PDL1 western blot might help to detect specific proteins in tissue homogenate. Mutational findings from targeted NGS panels can be correlated with response, but until today targeted NGS panels were not able to predict response to checkpoint inhibitors. Looking at DNA only provides limited information therefore, if we understand mRNA as a molecule reflecting the dynamic nature of a cancer cell, we should focus on investigating the cancer transcriptome in future.

Open access funding provided by Paracelsus Medical University.

Conflict of interest G. Hutarew declares that he has no competing interests.

Open Access This article is distributed under the terms of the Creative Commons Attribution 4.0 International License (http://creativecommons.org/licenses/by/4.0/), which permits unrestricted use, distribution, and reproduction in any medium, provided you give appropriate credit to the original author(s) and the source, provide a link to the Creative Commons license, and indicate if changes were made.

\section{References}

1. Kerr KM, Nicolson MC. Non-small cell lung cancer, PD-L1, and the pathologist. Arch Pathol Lab Med. 2016;140:249-54.

2. Vogelstein B, Papadopoulos N, Velculescu VE, et al. Cancer genomelandscapes. Science. 2013;339:1546-58.

3. Lawrence MS, Stojanov P, Polak P, et al. Mutational heterogeneity in cancer and the search for new cancerassociated genes. Nature. 2013;499:214-8.

4. Herbst RS, Soria JC, Kowanetz M, et al. Predictive correlates of response to the anti-PD-L1 antibody MPDL3280A in cancer patients. Nature. 2014;515:563-7.

5. Hamanishi J, Mandai M, Matsumura N, et al. PD-1/PD-L1 blockade in cancer treatment: perspectives and issues. Int J Clin Oncol. 2016;21:462-73.

6. Kerr KM, Tsao MS, Nicholson AG, et al. Programmed deathligand 1 immunohistochemistry in lung cancer: in what state is this art? J Thorac Oncol. 2015;10:985-9.

7. Topalian SL, Hodi FS, Brahmer JR, et al. Safety, activity, and immune correlates of anti-PD-1 antibody in cancer. N Engl J Med. 2012;366:2443-54.

8. BrahmerJR.PD-1-targetedimmunotherapy: recentclinical findings. Clin Adv Hematol Oncol. 2012;10:674-5.

9. Brahmer JR. Harnessing the immune system for the treatment of non-small-cell lung cancer. J Clin Oncol. 2013;31:1021-8.

10. Sznol M, Chen L. Antagonist antibodies to PD-1 and B7$\mathrm{H1}$ (PD-L1) in the treatment of advanced human cancerresponse. Clin Cancer Res. 2013;19:5542.

11. Gettinger S, Rizvi NA, Chow LQ, et al. Nivolumab monotherapy for first-line treatment of advanced nonsmall-cell lung cancer. J Clin Oncol. 2016;34:2980-7.

12. Borghaei H, Paz-Ares L, Horn L, et al. Nivolumab versus docetaxel in advanced nonsquamous non-small-cell lung cancer. NEngl J Med. 2015;373:1627-39.

13. Brahmer J, Reckamp KL, Baas P, et al. Nivolumab versus docetaxel in advanced squamous-cell non-small-cell lung cancer. NEngl J Med. 2015;373:123-35.

14. Warth A, Muley T, Meister M, Weichert W. Preanalytics in lung cancer. Recent Results Cancer Res. 2015;199:71-84.

15. Passiglia F, Bronte G, Bazan V, et al. PD-L1 expression as predictive biomarker in patients with NSCLC: a pooled analysis. Oncotarget. 2016;7:19738-47.

16. Gettinger SN, Horn L, Gandhi L, et al. Overall survival and long-term safety of nivolumab (anti-programmed death 1 antibody, BMS-936558, ONO-4538) in patients with previously treated advanced non-small-cell lung cancer. J Clin Oncol. 2015;33:2004-12.

17. Antonia SJ, Lopez-Martin JA, Bendell J, et al. Nivolumab alone and nivolumab plus ipilimumab in recurrent smallcell lung cancer (CheckMate 032): a multicentre, openlabel, phase 1/2 trial. Lancet Oncol. 2016;17:883-95.

18. Rizvi NA, Hellmann MD, Brahmer JR, et al. Nivolumab in combination with platinum-based doublet chemotherapy for first-line treatment of advanced non-small-cell lung cancer. JClin Oncol. 2016;34:2969-79.

19. Herbst RS, Baas P, Kim DW, et al. Pembrolizumab versus docetaxel for previously treated, PD-L1-positive, advanced non-small-cell lung cancer (KEYNOTE-010): a randomised controlled trial. Lancet. 2016;387:1540-50.

20. Garon EB, Rizvi NA, Hui R, et al. Pembrolizumab for the treatment of non-small-cell lung cancer. N Engl J Med. 2015;372:2018-28.

21. Bussolati G, Annaratone L, Maletta F. The pre-analytical phase in surgical pathology. Recent Results Cancer Res. 2015;199:1-13. 


\section{short review}

22. RizviNA, Mazieres J, PlanchardD, etal. Activity and safety of nivolumab, an anti-PD-1 immune checkpoint inhibitor, for patients with advanced, refractory squamous non-smallcell lung cancer (CheckMate 063): a phase 2, single-arm trial. Lancet Oncol. 2015;16:257-65.

23. Fehrenbacher L, Spira A, Ballinger M, et al. Atezolizumab versus docetaxel for patients with previously treated nonsmall-cell lung cancer (POPLAR): a multicentre, openlabel, phase 2 randomised controlled trial. Lancet. 2016;387:1837-46.

24. Hirsch FR, Bunn PA Jr., Herbst RS. "Companion diagnostics": has their time come and gone? Clin Cancer Res. 2014;20:4422-4.

25. Massard C, Gordon MS, Sharma S, et al. Safety and efficacy of durvalumab (MEDI4736), an anti-programmed cell death ligand-1 immune checkpoint inhibitor, in patients with advanced urothelial bladder cancer. J Clin Oncol. 2016;34(26):3119-25.

26. Sholl LM, Aisner DL, Allen TC, et al. Programmed death ligand-1 immunohistochemistry - a new challenge for pathologists: a perspective from members of the pulmonary pathology society. Arch Pathol Lab Med. 2016;140:341-4.
27. Kerr KM, Hirsch FR. Programmed death ligand-1 immunohistochemistry: friend or foe? Arch Pathol Lab Med. 2016;140:326-31.

28. Teng MW, Ngiow SF, Ribas A, Smyth MJ. Classifying cancers based on T-cell infiltration and PD-L1. Cancer Res. 2015;75:2139-45.

29. ScheelAH, Dietel M, HeukampLC, etal. Harmonized PD-L1 immunohistochemistry for pulmonary squamous-cell and adenocarcinomas. Mod Pathol. 2016;29(10):1165-72.

30. Schalper KA, Kaftan E, Herbst RS. Predictive biomarkers for PD-1 axis therapies: the hidden treasure or a call for research. Clin Cancer Res. 2016;22:2102-4.

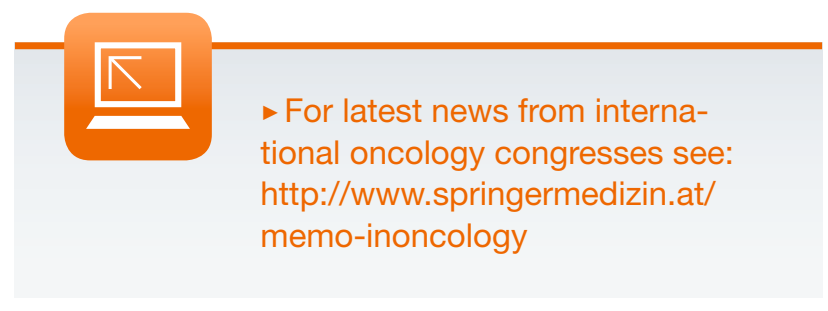

